\title{
Impact Of Social Media Advertising On High Energy Drink Preferences And Consumption
}

Patient Rambe, Central University of Technology, South Africa

Retumetse Joyce Jafeta, Central University of Technology, South Africa

\begin{abstract}
Despite the surging appropriation of social media by marketers for communicative marketing of brands, what remains under-explored in literature is the capacity of social media platforms to influence student preferences for brands. This research gap is ironic given the growing literature on the potential of self-images shared on social media to influence consumers' product preferences and purchase intentions. Drawing on Media Richness Theory, agency, extant literature and authors' personal reflections on social media adoption for brand selection by students, this theoretical study examines how students navigate such platforms to make informed choices about energy drinks. The findings suggest while students exploited social media platforms intermittently to access energy drink brands, their brand preferences and choices were informed by personal agency (especially personal volition, peer influences, convenience and availability of brands) more than social media networks per se. The study contributes a conceptual model that integrate social media appropriation, consumer decision making, brand preferences and purchases. While the model is untested, its methodological strength lays in its reliance on extant literature, proven concepts, anecdotes of student consumption behavior and authors' knowledge of social media, which are critical to deepening academics and policy makers' understanding of social media-brand preference relations in real world contexts.
\end{abstract}

Keywords: Social Media Advertising; Consumer Brand Preference And Monster Energy Drinks; Media Richness Theory

\section{INTRODUCTION}

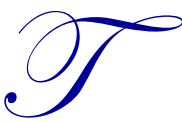

he transition from high school to university presents tremendous challenges to the healthy eating behaviours and tastes of students. As Deliens, Clarys, De Bourdeaudhuij and Deforche (2014) aptly suggest, as student independence increases with such a transition, so does the pressure to make healthy food choices. Given the energy intensive, cogitative processes students are involved in at university and the limited time at their disposal to prepare descent, healthy meals, students are often compelled to consume high energy drinks. Gatorade, Rockstar, Red Bull and PowerAde are the recognized high-energy brands among college students in the United States (Kashani, 2010).

The US energy drinks market, forecast to reach 21 billion in the Year 2017 (Food Product Design, 2013) has been exploited by 30 percent of adolescents who reported regular use (Seifert \& Schaechter, Hershorin \& Lipshultz, 2011). In fact, extant literature is replete with evidence of student consumption of such beverages (Chesnut, 2010; Seifert, et al., 2011; Institut National De Santé Publique Du Québec, 2013; Hossain, Azad, Parveen, Masum, 2014). In essence, the high caffeine content and reported mind stimulating effects of high energy drinks make them ideal for consumption by students during their private study or preparation for exams. Yet, the intake of energy drinks is also associated with physiological and psychological constraints like reduced alertness and weakened mental capabilities (Hossain et al., 2014). Other studies report healthy risks and distractive impacts of excessive intake of such beverages, which include mild to moderate euphoria, agitation, anxiety (Alford, Cox \& Wescott, 2001; Van Den Eynde, Van Baelen, Portzky, Audenaert, 2008).

In the absence of knowledgeable parents and adults to advise students on balanced diets and proper eating habits, students resort to social media networks and peer networks for advice on good eating behaviours. While student eating 
could be a consequence of personal tastes, self-discipline, accessibility and cost of such brands, (lack of) parental control, friends and peers also shape the energy drink consumption habits of students (Deliens et al., 2014). More so, as competition for brand recognition increases among beverage brands, beverage companies have resorted to aggressive marketing strategies and tactics such as the use of social media websites, television commercials, celebrity sponsorship and demonstrations (Kashani, 2010) to size hold of the young adult target markets.

As consumer preferences for brands are growing with increased exposure of consumers to vast amounts of web-based information (Schultz \& Block, 2011), marketers are compelled to make claims or promises about their services or products (Silverman, 2001) through the most accessible, available technologies such as social media. Consistent with Media Richness Theory, marketers are encouraged to engage with online media, which reduces vagueness of messages, deepen customers' knowledge of brands and increase marketers' knowledge of consumers' tastes (Daft \& Lengel, 1984; Bergin, n.d.). While many marketers and advertisers have resorted to the use of social media technologies and content repositories like YouTube for the communicative marketing of their brands (Dei Worldwide, 2008:2), what remains under-explored in literature is the capacity of social media platforms to influence student preferences for brands. To the extent that Media Richness Theory (MRT) considers communication that requires less duration to comprehend or deals with diverse viewpoints (Bergin, n.d), multiple modes of communication, and requires low cognitive load as potentially rich communication media, social media is no exception. MRT distinguishes various forms of communication media by their extent of richness namely: the quality of the feedback provided by the media, communication modes, level of personal detachment of messages; and diversity of languages of communication (Daft \& Lengel, 1984; Mandal \& McQueen, 2012). Since social media platforms support various channels of communication, allow multiple interactants (marketer-customer, customer-marketer, customer-business and business -customer interactions) including synchronous and asynchronous interactions, they constitute rich forms of media that deserve further interrogation in marketing and advertising domains.

Although trade publications report that consumers are now using social networks to browse and access company products and services compared to company websites (Dei Worldwide, 2008:2), what remains speculative in literature is the impact of social media marketing on brand preferences (Ni, Jiang, \& Srinivasan, 2014). In view of this research gap, our theoretical study seeks to explore the influence of social media on student preferences for popular brands they consume such as high energy drinks. Such an investigation is critical to understanding the transformative effects of social media marketing in view of the claim that interactive social media is changing how the generation, sharing and consumption of content happens, thus shifting the authority to shape perspectives on brands from advertisers to consumers through online connections (Muntinga, Moorman \& Smit, 2011).

\subsection{Problem Background and Problem Statement}

The obscurity of knowledge on how students adopt social media platforms to make decisions about brands is deeply implicated in: the evolution of the web and the changing roles of consumers, the growth of peer networks, which trigger affinity-based drink recommendations, the push-pull dynamics of advertising and the evolution of multigeneration brands. These antecedents to or drivers of social media-based brand preferences are discussed in greater detail in the problem background sections below.

\subsubsection{Web Evolution and Reversal of Roles}

The limited knowledge about how social media is shaping and influencing youth's (especially university students) brand (e.g. high energy drink) preferences can be approached from the perspective of evolution of the sematic web and the subversion of traditional authority in advertising and online publishing. Traditionally, brand and marketing managers had more authority over consumers through their capacity to package and transmit brand messages, influence the brand preferences and purchasing psyche of consumers through: newspapers, radio and electronic broadcasting of promotions and advertisements. In view of the popularity of the Semantic Web and networked technologies, which is founded on social interaction, creation and free sharing of content as well as the creation of new dynamics for online marketing, the marketer-consumer power relations are reconfigured in favour of consumers (Hay, 2009). In a university context, therefore, students can recommend high energy drinks to their peer networks through: tagging of preferred energy brands on Facebook, representing and communicating their drink choices by following celebrities' endorsements on Twitter, and through live streaming of their preferred drinks on content 
platforms (e.g. YouTube videos). In fact, social media has changed communication channels from a hierarchical monologue of advertisers to multiple voices of customers, thereby transforming the way customers produce, consume, and interact with information, based on explosive migration to the web (Alhaddad, 2015). In this social networking revolution where consumers such as students can create content and share their brand (e.g. high energy drinks) preferences without any requirements for them to be technical experts, social media is likely to revolutionise the relationships among high energy drink marketers, retailers, channels of distribution (Alhaddad, 2015) and consumers. This further blurs our knowledge about such brand-based transactional exchanges.

Apart from the evolution of the web from content production by highly skilled content developers and producers towards the read-write web, brand preferences are implicated in the evolving architecture of consumer consumption of social media. Social media platforms have enabled the transformation of young technology users such as students from being consumers of content only to being producers and consumers synchronously - "prosumers" (that is consumers and producers concurrently) (Aguaded \& Ferrés, Cruz Díaz, Delgado-Ponce, 2011). Social media has also gradually popularised the electronic word-of-mouth by allowing the viral spread of brands such as energy drink choices of students through brand recommendations, social commentary, debates and affirmations through 'likes,' 'comments,' discussion forums, and private message features of social media platforms. In their study of the determinants of eating behaviour of university students, Deliens et al. (2014) report that students' food choices were informed by their peer-based social networks (e.g. friends and peers), individual factors, and physical environment (e.g. availability and accessibility, appeal and prices of food products). As new features have been added on social media platforms such as pictures, budges for affirmations, and groups for deliberating drink preferences, Keller (2012) envisages that pictorial and visual images in [social media] advertisements and web-based media can influence consumers to purchase food and alter their perceptions on what makes food appealing.

\subsubsection{Peer-Based Drink Recommendations and Evolving Food Choices}

As the semantic web and its features mature, so does peer-based sharing and advice on food choices via these platforms. Peer-based drink recommendations can emerge through social media platforms and the pscho-social support structures such as student associations and societies, which recommend drink brands tacitly through serving such refreshments during gathering or advertising them through their web-pages. Illumine Marketing and Media (2010) highlights that a majority ( $80 \%$ ) of social networkers prefer their online contacts' judgments and perspectives compared to those of other interactants. More so, many consumers peruse their online peers' views during their online shopping the same way their actual shopping behaviours are shaped by their online content. In addition, it was ascertained that $50 \%$ of consumers read other consumers views when shopping 'online', whilst $16 \%$ have been influenced by this online information when making purchases (Copyright Company, 2008). In light of these changes in trust from advertisers to consumers, critical questions on the shifting morphology of brand advertising and endorsements need to be posed to marketers so that they are able to understand customer brand preferences online.

\subsubsection{Creating Multi-Generation Brands}

One of the main reasons for our limited knowledge on how social media shapes youths' (especially students) brand preferences is the 'scotched earth' approach adopted by marketers, which involves the multi-generation marketing of energy drink brands. Because of the multiple variations in brand preferences across generations, multi-generational marketing by marketers often occludes an understanding of the preferences and consumption dynamics within a particular generation especially the youth such as students. Multi-generational marketing, describes a practice of appealing to the unique preferences, needs and behaviours of individuals within more than one specific generational group (Morris, 1982) to develop solid connections and intimate business relations (Himmel, 2008). Ageless, multigenerational advertising may compromise the capacity of marketers and brand owners to understand, account for and incorporate particular marketing strategies that appeal to and are appropriate for particular generational characteristics and behaviours. Hence the need for segmentation of products, services, and communication genres.

\subsubsection{The Push-Pull Dynamics of Advertising}

The often messy, elusive and fluid transactions between advertisers' marketing intentions and youths' brand preferences further compound a sober understanding of social media-enabled preferences for brands by students. The 
evolution of students' social media-informed preferences for energy drinks is not only informed by convenience access, availability, the task at hand (e.g. preparing for examinations and extending study hours) but also by the advertisers whose deluge of messages inundate students' social media pages. Pepsi's reluctance to promote their brand during the Super Bowl was attributed to their commitment to use social media platforms to increase awareness of their brands. During the same period, Coca Cola employed the Super Bowl to advertise its humanitarian concerns via social media platforms (WARC, 2010). The global reach of social media presents opportunities for marketers to access students with implications for business success (WARC, 2010). If advertisers will ultimately follow audiences, then social media's appeal to expansive and difficult-to-reach audiences like students, should somehow translate into commercial success for marketers and social media operators.

However, more often than not, young consumers especially students are naturally 'pulled' to social media platforms primarily for enjoyment and socialization as opposed to the 'push' strategy adopted by marketers when marketing brands. Bhargava (2010) argue that consumers such as students conceive such web platforms as spaces for socialising and banter rather than promotion platforms. In fact, the challenge for brand managers, marketers and advertisers lays in how to transform social media from a cool, lay back entertainment 'rendezvous' to a serious marketing space for optimising the expression of preferences of brands by young adults, who constitute heavy users of social media.

The problem, therefore, lays in the preferences schism between traditional marketers and consumers such as students. On the one hand, marketers across the globe are increasingly preoccupied with using social media advertising to create brand awareness, brand image and brand equity (Alhaddad, 2015) in ways that seize hold of consumers' preferences, to optimise value for their brands and businesses. On the other hand, consumers have exploited the interactive affordances of social media to become more demanding to marketers and service providers, to individualise their preferences, caution and educate each other on products (Sheth \& Mittal, 2004; Arora, 2013). Therefore, customers are exploiting social media platforms to entrench information seeking, decision making and facilitate prudent purchase transactions (Raaij, 1998; cited in Ivanauskas, 2009) in ways that potentially leverage their purchasing power and agency. Social media data constitutes consumer-generated media that consumers are actively creating, using and circulating to familiarise each another on products and services (Blackshaw \& Nazzaro, 2006). In view of this tug-ofwar between marketers' relentless attempts to influence consumers' preferences and purchasing decisions, and consumers' commitment to adopt social media to take control of their brand preferences, critical questions can be posed on how customers (especially university students) are harnessing social media to make un/informed choices about available brands (i.e. high energy drinks). Since user generated content is generating renewed confidence among consumers about brands and increasing social networked communities' dependence on such content (Freshman Consulting, 2010), we wondered about how students appropriate social media to make choices about high energy drink purchases.

\section{MEDIA RICHNESS THEORY}

Given the communication gaps between brand marketers and/ advertisers who use social media technologies, grasping the fact that communication efficiency depends on users' networked interactions, the appropriateness of technology (or media) in use and communication task traits, cannot be understated. Media Richness Theory, which considers the richness of communication as an outcome of media quality, regards the richness of media to be a consequence of it capacity to bring a shared understanding in a given duration (Daft \& Lengel, 1984). Communicative exchanges that address various modes and deal with ambiguity or improve the quick grasp of content are conceived as rich (Daft \& Lengel, 1984). In the context of social media, the opportunities for dialogic and conversational interactions through: social commentary about energy drink brands by consumers, following and soliciting the perceptions of opinion leaders, brand ambassadors and celebrities, critiquing through online networked communities and securing feedback from brand managers and advertisers potentially reduce the ambiguity of messages about energy drink brands. Communication exchanges that are complicated or fail to address divergent perspectives are perceived as low in media richness (Daft \& Lengel, 1984). The social media's affordances for multiple commenting and viral critiquing by a less informed general public may be a recipe for miscommunication as they may trigger misleading messages, ambiguities about brand choices and role confusion as brand managers, brand ambassadors and consumers jostle for recognition as consultants, advisors and resource persons in the advertising charade. 
To the extent that Media Richness Theory (MRT) was drawn upon in diverse technology, academic (Shepherd \& Martz, 2006; Chen, Chen \& Kazman, 2007; Aljukhadar, Senecal \& Oullette, 2010; Lan and Sie, 2010) and commercial environments (Simons \& Peppas, 2004; Sukoco \& Wu, 2010; Shiue, Chiu \& Chang, 2010), the theory provides a robust analytical and empirical lens for interrogating technology-mediated consumption of energy drinks (Lan \& Sie, 2010). This study draws on this theory's concepts such as content richness, content accuracy, and content adaptability, to explore how social media networks shape consumer perceptions of brands and influence their purchasing behavior. While content heterogeneity and adaptability on social media manifests in a diversity of graphic, pictorial, video and audio messages, multiple comments peddled on such platforms and the openness to manipulation of such messages by multiple audiences respectively, the accuracy of social media content remains heavily debatable. This because the frontiers between experts with disciplinary knowledge and novices lacking such knowledge are blurred on such platforms.

MRT proposes that the decisions to consume different communication media (e.g. between email and voice mail) will vary with the degree of uncertainty or equivocality in the communication task (Markus, 1994). As mentioned earlier, rich media tends to promote unequivocal communication than that media ranked lower on the richness scale (Markus, 1994). To the extent that voice blogs (e.g. voblogs) and social media live streaming could be considered to provide verbal, paraverbal and non-verbal cues about individuals' emotional dispositions, intonations and accents than static text, they are richer and better positioned to influence customer brand preferences and perhaps, brand purchasing decisions. Therefore, social media live streaming, voblogs, and vmail serve as richer media than textual messages in terms of their capacity to convey multiple cues and promote messages with various cues (Shepherd \& Martz, 2006), which are critical in influencing student choice of brands and their ultimate purchasing decisions. In spite of the relevance of the MRT in explaining customer brand preferences and consumer behavior, the theory is limited to the extent that it fosters technological determinism by emphasising technological affordances and capabilities as the main determinants of consumer behaviour. An over-emphasis on technology reduces individuals to appendages and objects of technology, rather than recognise them as agents implicated in advertisers and brand managers' advertising escapades. Mindful of this limitation of MRT, this study draws on the concept of individual agency to complement this theory's shortcomings with regard to individual decision making.

\section{CONCEPT OF AGENCY}

The concept of agency is heavily contested in mainstream literature (see Vallacher \& Wegner, 1989; Archer 2000, World Bank, 2012; LaPointe and Heilmann, 2014). The World Bank (2012:150) defines agency as an individual's (or group's) ability to use their endowments and take advantage of economic opportunities availed to them." In the context of a media-saturated environment such as social media-enhanced brand consumption, therefore, agency describes the capacity and capability of the consumer (in this case the student) to deploy social media as a deliberative platform to make informed choices about brand preferences as well as transform these choices into prudent purchase decisions. In offline environments, agency describes individuals' capacity to make and act upon their own choices (LaPointe \& Heilmann, 2014) drawing on particular material (e.g. technology), intellectual (e.g. knowledge, information and wisdom) and social (e.g. social friendships, ties and networks) resources. Applying individual and social agency to brand purchases, it can be inferred that students' decisions to purchase energy drinks are not only influenced by the transactive character and discursive possibilities of social media technologies but rather by students' volition, social network influences, and contextual factors such as the availability and pricing of these brands.

\section{LITERATURE REVIEW}

\subsection{Social Media}

Kaplan and Haenlein (2009:565), define social media as "Internet-based applications that help consumers share opinions, insights, experiences, and perspectives". Social media, which describes Web-based interactive software distinguished for the biographical nature of its profiles, dialogic character of its conversations, temporality of interactions and user-oriented nature of networks (Rambe, 2012), has multiple variations.

Statistica (2016) highlights that the leading social networking sites worldwide as of January 2016, ranked by the number of active users were: Facebook (1.5 billion), WhatsApp (900 million), Facebook messenger (800 million), 
WeChat (650 million), Instagram (400 million), Twitter (320 million) and Skype (300 million) and LinkedIn (100 million). Given the wide reception of social media technologies, much literature on social media-based marketing of energy drinks has interrogated inter alia: developing user loyalty for social networking sites (Gu, Oh \& Wang, 2016), the social construction of masculinity and militarized consumptions of energy drinks (Chesnut, 2010), and improving brands' appeal through social commentary (Spiegler, Michahelles \& Hildebrand, 2011). These studies, however, did not necessarily focus on university students preferences of high energy drinks. The few exceptions, which have examined inter alia; drink brand recognition among university students (Kashani, 2010), advertising and consumerism in the food industry (Keller, 2012) have not focused on social media-mediated brand preferences. In Kashani's (2010) study, college students accessed and recognised functional drink brands through television, magazines and the internet but rarely through social media platforms. Her findings contradict Dei Worldwide's (2008) claim that consumers now use social networks more frequently than corporate websites when searching for information on a company, brand or product. Such a contradiction provided an impetus for the current study.

Research on social media has focused on areas such as brand user segmentation and participation (Berthon, Pitt, \& Campbell, 2008; Temkin, 2010); electronic word-of-mouth communication (Okazaki, 2009; Riegner, 2007); and online brand communities. Even through Web 2.0 platforms are creating new opportunities for social marketers to shift their practice away from the traditional communication flow where messages are relayed through a channel to a receiver or target audience towards user generation of content (Thackeray \& Neiger, 2009), it is unclear how students enact their agency and negotiate their preferences of brands via such platforms. For on-campus college students in South Africa who might have limited access to electronic broadcasting such as television but enjoy free access to the World Wide Web and social networking sites, their brand preferences can be shaped by high energy drink companies' websites, their Facebook brand and fan pages and celebrity brand endorsements.

\subsection{Brand Awareness}

Brand awareness is often the focus of brand strategy and refers to the strength of the brand's presence in the market place (Aaker, 1996; Aaker \& Joachimsthaler, 2000). It is the accessibility of the brand in the consumer's memory while brand association is anything linked to the brand in the consumer's mind (Chattopadhyay, Shraddha \& Krishnan, 2010:67). Brand awareness provides consumers with a sense of familiarity and entrenches brand presence, commitment and substance in the market place (Subhani \& Osman, 2009). A study conducted by Kashani (2010) revealed that after bottled water, the most recognised and purchased drinks were high energy sport beverages such as Gatorade and PowerAde due to their close association with physical fitness, sporting activities and their marketing, which targeted athletes and spotting personalities. For instance, $70.7 \%$ of sport drink consumers said they considered themselves to be "somewhat healthy" and $85.4 \%$ of those who purchased them exercised at least 1-2 times per week (Kashani, 2010). The desire for weight loss, availability of money to spend, obesity, and higher intensity of alcohol use were positively associated with the use of gyms and consumption of high caffeinated energy drinks (Reid, Hammond, McCrory, Dubin, Leatherdale, 2015).

As a primary dimension of brand equity, brand awareness remains fundamental to a consumer's purchase decision as it is the initial interaction point between the brand and the consumer (Susic, 2014). Forming positive brand images maximizes brand loyalty and builds the foundation for brand equity. Susic (2014) examined plain packaging of caffeinated energy drinks to establish if it can effectively reduce the attractiveness of the product, and as a result, decrease consumption. The survey results reported that plain packaging does not affect the customers' attitudes and perceptions of a product, typical use or taste purchase intention negatively, but rather positively. This was mainly due to the decreased differentiation between brands such that plain packaging is an outcome that is in favour of neither the customers nor brands (Susic, 2014). Moore's (2009) findings revealed that brand image or taste influenced college student preferences for energy drinks. The results revealed that Red Bull was the most preferred drink (47\%), while in the blind taste tests, Monster was most preferred (28\% of respondents chose it as their favourite).

\subsection{Social Media Brand Awareness}

The increasing involvement of social media in business advertising has enabled firms to produce new avenues of communication, which allow existing consumers and prospective consumers to be reached as a targeted audience (Batra, Ahuvia \& Bagozzi, 2012). Social media platforms can be utilised to promote brands with the intention of 
influencing consumer decisions. Social media brand awareness, therefore, means increasing the extent of brand familiarity and brand presence for customers through the mediating effects of social media advertising (Subhani \& Osman, 2009).

One of the primary foci of social media advertising is shaping consumer behaviour. For instance, in the marketing of energy drinks such as Red Bull, marketing claims of performance-enhancing effect, concentration, reaction speed, and boosting metabolism are made (Red Bull Website, 2008). More so, mental seduction manifests in manipulating customers into believing that drinking more energy drinks will make them realise the stated desires (Hossain et al. 2014). The influencing of consumer behaviour does not only represent swaying consumer's preferences using specific images and specific people but also highlights the needs and shortcomings consumers never thought they had (Bogomolova \& Milibum, 2012). Moore's (2009) study on college students' preferences of energy drinks revealed that they were more sceptical about advertising, and even though they were still influenced by marketing efforts, there was a discrepancy between their stated preferences and the tested taste preferences. This buttresses the claim that high energy drinks like Mountain Dew, Red Bull and Monster Energy, are being promoted as alternatives to illicit drugs (Cruse, 2007) as they mask intoxicated feelings that allow increased alcohol consumption (Fornicola, 2007; Hossain, et al., 2014).

Social media serve as channels to gain popularity or recognition of talent of various stakeholders (TechCrunch, 2012), and as platforms for the reconfiguration and re-channelling of brand preferences of customers. Organizations are not only able to reach customers online and interact with them; but become part of customer conversations (Kaplan \& Heinlein, 2010). Brand managers and advertisers are attempting to utilise social media to reach existing customers, gain new ones, and build or maintain credibility and reputation (Kaplan \& Heinlein, 2010). Brand managers and advertisers of energy drinks may attempt to access the youth especially university students through: developing websites on which they display enticing messages about their energy drinks, allow consumers to post brand messages and consumption suggestions on social media fan pages, conduct on-campus promotions and giveaways where they give the energy drinks for free to prospective buyers, and create web-based communities and newsletters in which they articulate their drink brands. Despite this potential, there is infrequent research that emphasises the capacity of social media to shape, inform and influence brand preferences of consumers in general (Arora, 2013; Alhaddad, 2015; Karam \& Saydam, 2015) and of student preferences for high energy drinks in particular.

\subsection{Consumer Brand Preferences}

Brand preferences involve a consumer's choice and potential purchase of a product for consumption. For example, University students may consider Red bull, Monster energy, Gatorade, Rockstar, and PowerAde as their preferred drinks for boosting glucose, sugar and energy levels to extend their study time especially during exam preparations and the write up of assignments. Although the nutritional value of energy drinks (e.g. their glucose content and energy levels) may be at the core of the intake of such drinks, availability of such drinks and peer influences may have critical influences on the preferences and consumption of these drinks. Mcdonald and Bradely (2012) believe that other factors such as pricing and quality of the product may also affect the consumer preferences and buying behaviour of brands. The endorsement of energy drinks by popular personalities (e.g. dieticians, physicians, sports persons, actors and TV personalities) is another way through which consumers' exposure to advertising impacts their choice and propensity to purchase brands. However, more often than not, the endorsement of brands by popular personalities only assists when that brand is introduced to the masses. Therefore, gaining trust from consumers that are already loyal to another brand can be challenging (Bernard, Hudson, Hunter, Liu \& Murphy, 2008).

Apart from availability and pricing of brands, consumer brand preferences can also unfold through virtual communities such as Facebook fan pages and forums, following Twitter opinion leaders and live streaming of YouTube videos. Student preferences for energy drinks, therefore, can also arise from their participation in online and social networking community activities such as consuming content on energy drink flavours, sharing knowledge of their nutritional value, experiences and opinions about their caffeine content as well as discussions on general life styles among consumers online (Heinonen, 2011). Internet is, therefore, a social place that has created new forums for consumers. Virtual communities, blogs, and social networking sites provide a platform to influence consumers' purchase decisions (OTX Research, 2008) and social forums for the exchange of experiences and lifestyles of students. 
Once initiated through a desire for a good or service, consumer brand preferences may be sustained to create a particular consumer behavior. Specific consumer behavior describes "the activities people undertake when obtaining, consuming, and disposing of products and services" (Blackwell, Miniard \& Engel, 2001:6). Such consumer behavior can be initiated and sustained via online social networks. While social network personalities and features such as prominent individuals and group forums respectively can exert influence on consumers with regard their purchase decisions (Solomon, Bamossy, Askegaard, \& Hogg \&, 2010), the exchange of brand information, comments, reviews, and rates via online social networks can also shift purchasing decisions in varied ways (Heinrichs, Lim \& Lim, 2011).

\subsection{Brand Preferences Among the Youth}

Since students often depend on peer networks for information and advice, it plausible for university students to make consumption decisions based on observation, imitation and mimicry of friends, peers and social networks. The translucence of social media platform activities and the permanence of digital trails of their informal conversations (Rambe, 2009) enable peer networks connected to each other to trace, visualize and understand the ignorant and knowledgeable others' life styles, experiences, perspectives on particular brands. In social media networks, there are multiple scenarios where users' behaviours, their thoughts and products they purchase are shaped by others (Aaker, 1991:622).

Our interest in the youth especially university students is informed by the dominant idea in the marketing literature that the youth is a prototypical global segment, having similar practices and desires (Kjeldgaard \& Askegaard, 2006). In their search for new alternatives to create their identities including their brand preferences, the youth serves as a social agent through which global products and practices can enter into the local context. For instance, although advertisements about global brands such as Monster Energy and Coca Cola can be conceived as cross-generation, attractive youth are often exploited for the marketing of such brands to increase their emotional, acoustic and aesthetic appeal (Thompson \& Arsel, 2004). However, the youth also serves as agents of globalization itself (Thompson \& Arsel, 2004) by adopting and adapting such global practices to suit their cultural norms. For instance, energy drink consumption is associated with partying, popular culture music and peer influences, which can be conceived as a youth phenomenon.

Bashar, Ahmad \& Wasiq (2012) conducted a study on the extent to which social media helps consumers in making decisions to buy products. Results of their study suggest that social media as media of communication about consumer brands is exploding at an exponential rate and has immense potential in spite of its perceived infancy. As part of attracting customers' attention and influencing their decision-making about brands, advertisers may draw on advertising memorability via social media. Advertising memorability for the youth such as students involves brand managers and advertisers engaging students in innovative advertisements that are captivating and engaging (Alhaddad, 2015). These enjoyable advertisements could involve animals, nostalgia, children and music; and less likely to be based on a real person or manufacturer endorsements per se (Alhaddad, 2015). Yadav (2012) used case studies to evaluate the significance of social networks as advertising media rather than real individual characters. The study demonstrated that social websites are not just tools for interacting with different people but constitute media for reaching the prospective customers, and different spectrum regionally and globally.

\section{PROPOSED CONCEPTUAL FRAMEWORK}

The flow diagram above suggest that while social media brand awareness presupposes the influence of social media in increasing consumer awareness about brands, consumer decision making about brands can happen with or without the influence of social media (see the arrow leading to consumer decision making in Figure 1). Consumers (i.e. students) have a choice to exercise their own volition with regard decision making (that is, their individual agency) about brands or to consult with their peers via social networking sites (collective agency) or both. If consumer brand preferences are activated via social media (that is, through social media brand awareness), Media Richness Theory can serve as an important lens for understanding how students make such choices drawing on social media. To the extent that Media Richness Theory considers the strengths of various media in giving immediate feedback, personalization of messages, the ability to use natural language, and transmission of nonverbal cues (Dickinson, 2012), social media platforms' asynchronous communication affordances, multiple communication channels (private messages and public forum discussions) and their various modes (text, audio, video and graphics) may provide ideal 
opportunities for students to make appropriate brand preferences and decisions about energy drinks. Since decision making about brands can be an ad hoc, serendipitous, and continual activity for those students with high spending power, as much as it can involve a deliberately calculated process of weighing available brand options for those students from socially disadvantaged backgrounds with limited propensity to spend, the opportunities for mediated presence and collective decision making enabled by social media can generate a rich deliberative platform for dealing with task complexity (i.e. making decisions about available energy drink brands).

Figure 1.

Factors/variables

Intervening variables

Outcome variables

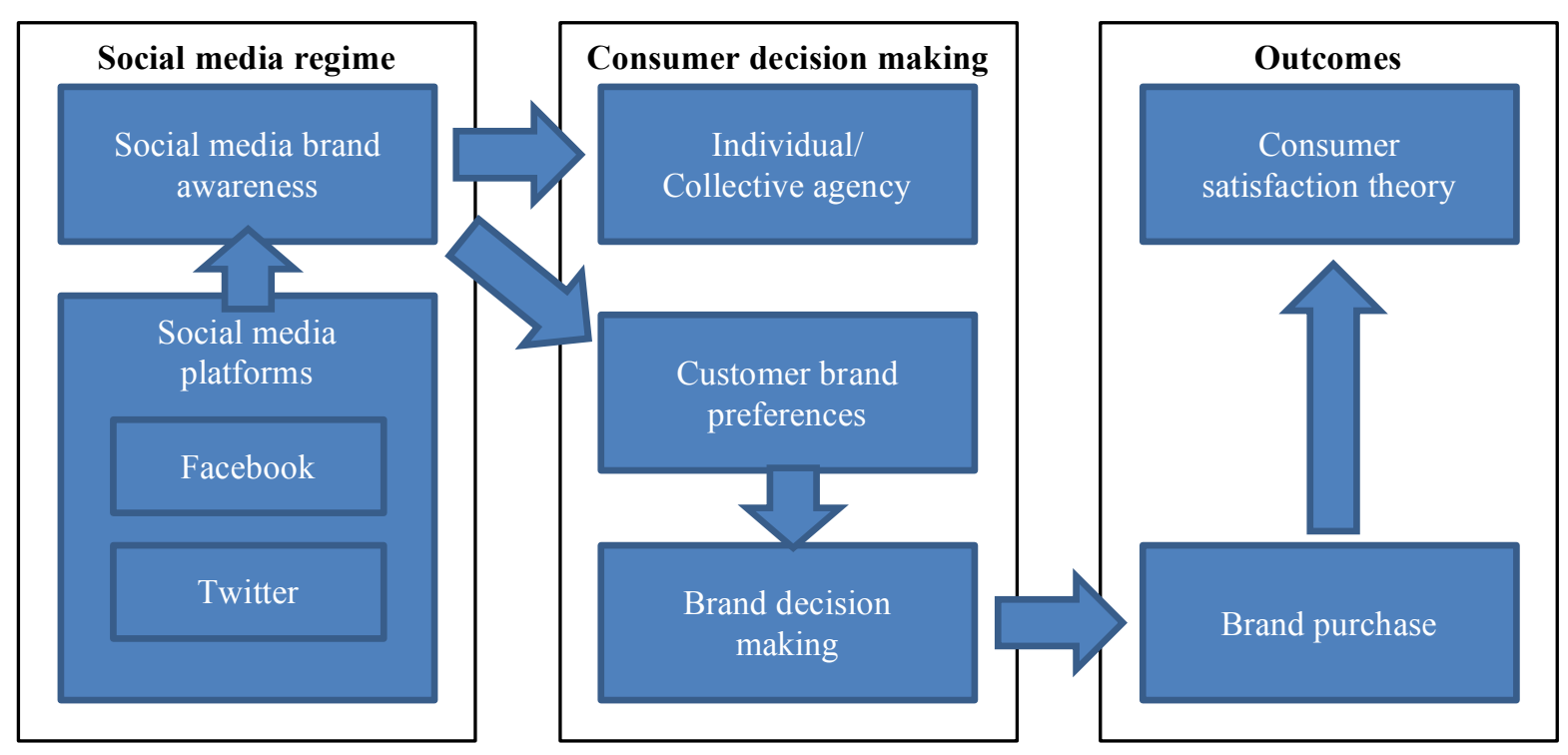

Since businesses' social media pages such as Facebook may render non-verbal language such as photographs of brands and videos of their consumption by consumers, such communication may be considered to be richer than e-mails messages. However, it does not always follow that video-based and pictorial messages bring about more richness than text-based messages. Mandal and McQueen's (2012) study on social media adoption by microbusinesses found limited customer engagement with brand photos via Facebook. Their study also revealed that on the contrary, simple text messages sometimes evoked greater responses, indicating that the communicating partners socially constructed the context and did not need richer media for communication and to engage with each other or without social media. This view supports our argument about the capacity of consumers to socially exchange messages and engage with each other with or without social media.

Apart from Media Richness Theory's preoccupation with multiple channels/modes of communication of social media, social media marketing emphasizes marketing managers and advertisers' hosting of online discussions, where they welcome comparisons to their competitors' products and value group information sharing (Barker, Barker, Bormann, $\&$ Neher, 2013). Another aspect not necessarily explained by Media Richness Theory's alignment of communication mode to task complexity is that social media marketing managers and agents emphasize audience's contribution to content and relaxation of their controls on content. This means that while they may influence what consumers say and think about their brands, they rarely control the conversations entirely (Barker et al., 2013). As such, unlike Media Richness Theory that foregrounds the richness or leanness of communication purveyed through particular media with implications for task simplicity or complexity, social media advertising emphasises building trusting relationships between the consumers and brand advertisers. 


\section{METHODOLOGY}

This paper adopts a theoretical stance. A research is theoretical if its purpose is to draw upon currently published research literature with the aim of furthering theoretical work in the field of interest (University of Sydney, 2002). According to Wacker (1998) a theoretical paper draws on conceptual concepts and definitions, theoretical domain limitations and predictions to provide a framework for analysis critical to the efficient development of the field of research. The purpose of the study is to explore the relationships among social media networks, social media advertising, brand awareness, brand preferences, band decision making and ultimately, ultimate purchases of brands. To the extent that a theoretical research is based on the observation of others and runs no analytical procedures due to absence of empirical data (Georgia State University, 2015), the current study draws on mainstream literature on social media and consumer behaviour and the authors' personal reflections, due to the paucity of literature that explores the interface of social media, advertising, student brand preferences, and purchase decisions.

\section{FINDINGS BASED ON EXTANT LITERATURE AND AUTHORS' REFLECTIONS ON THEIR INFORMAL CONVERSATIONS WITH STUDENTS}

While consumers used to shop at retail chains such as shopping malls, and a majority are still intrigued by this purchasing mode (Hsiao, 2009), the sprawling of social media platforms is believed to have transformed the dynamics of the electronic market place and online purchasing through the multiple roles and identities (as social networkers, inquirers about brands, social commentators, resource persons and knowledge workers) that youth are increasingly called upon to assume. While no single factor may explain an entire online marketplace's success or failure, there is a consensus that high-quality communication among buyers and sellers may be a critical success factor (Liu \& Arnett 2000) for online transactions. In reference to our study involving the use of social media platforms (especially Facebook, WhatsApp), brand managers, brand ambassadors and advertisers are considered to interact with consumers (i.e. students) by proxy, that is, by posting energy drink brands on consumers' Facebook timelines or WhatsApp pages. Social media marketing is distinguished from traditional advertising by three aspects: its focus on creating buzzes or newsworthy events, tweets, video entries that attract consumers' attention and go viral though user-to-user contacts, creating mechanism for brand fans to promote brands through multiple social media channels and promoting user online participation and dialogue through online conversations (Barker, Barker, Bormann \& Neher, 2013).

Inconsistent with Media Richness Theory, which emphasises content richness, content accuracy, and content adaptability, the advertisers and brand managers' interactions with consumers (students) on the electronic market places (i.e. social media platforms) are very deficient, artificial, ad hoc and temporal as they are based on once-off encounters and purchases (Ba \& Pavlou 2002; Rietjens 2006). Indeed, online marketplaces are characterised mostly by single-shot transactions (Ba \& Pavlou 2002; Rietjens, 2006) that complicate continued conversations between buyers and sellers that enrich consumers' knowledge of brands. In the second author's informal conversations with office management students she taught, and our personal reflections on student engagements with brand advertisers on Facebook, we inferred that while students recognized the Monster Energy and Play drink advertisements that advertisers post on Facebook and WhatsApp, students did not pay much attention to these advertisements as a sources of information on these brands. This could be due to the lean, uninformative content in these advertisements, the supposedly misleading advertisements about the nutritional content of these drinks and ephemeral nature of these transactional exchanges. Inconsistent with the principle of content accuracy encapsulated in Media Richness Theory, and contrary to advertisers proclamations about the rich nutritional value of Monster Energy drinks, the second author's informal conversations revealed that student athletes who had tasted Monster Energy claimed that this energy drink tasted bad, was unhealthy, did not provide the high energy claimed by advertisers but rather made them feel dizzy.

With regard to content richness, student generally felt that Monster Energy was poorly marketed as some had not encountered media rich advertisements on it. Some students claimed that the Monster Energy logo looked scary, unappealing and demotivated customers. Some students complained that the brand managers of this drink had failed to counter the negative publicity especially the unsubstantiated demonic character of the drink. The flippant, fleeting conversations among students on energy drink brands such as Monster energy and Play occurred between students and their peers via "likes" "sharing" and notifications about these brands. These comments and communications were not necessarily directed at advertisers or brand managers, even though the translucence of the platforms allowed them 
(advertisers and brand managers) to see these positive affirmations, which might have inadvertently influenced their brand marketing strategy. Overall, consistent with individual agency, we argue that the interactions between social media band awareness and brand purchase by consumers (i.e. students) was not always direct but rather was mediated by individual and collective agency, which might or might not be socially constructed drawing on social media. That is, in some instances, social media brand awareness can influence consumer brand preferences - as the students gets familiar with the brand, they develop trust in the brand leading to positive decision making about it, which can result in brand purchase. We will call this an opportunistic transaction and impulsive purchase respectively. Alternatively, even with social media brand awareness, the student may need to exercise agency by applying their mind about the brand, ranking the brand against its substitutes or competitors, and ranking their purchase priorities against this brand, before they have their preferences. Even when they prefer this brand, they still have a choice to purchase or not to purchase the brand. We coin this rational purchase behaviour.

The frequenting of social media platforms is improving customers' access to their most desired products and services online. The negative energy of Monster Energy advertisements reported among students can be contrasted with the Play energy drink advertisements on social media (especially Facebook), which students generally considered to be more user friendly and attractively displayed for them to subsequently go and taste this energy drink. This perceived visual appeal and content richness, however, does not sufficiently counter the indirect interaction between advertisers and students, whose only staple form of interaction is via advertisements on social media. This can be contrasted with Chesnut's (2010) study which reports on how the rhetorical overtone in PespiCo's Mountain Dew (a high-octane recruitment commercial) appeals to and is effective in articulating the masculine risk taking behaviour such as extreme sport and war. The effectiveness of such rhetorical overtones of advertising agents can be context dependent - they can work if strategically articulated around exam time when students are more inclined to the consumption of energy drinks during exam preparation and before seating for examinations. The conjecture of war impulses and martial combat in Mountain Dew commercials resonate well with examination preparations by students, which are often paralleled with mortal combat, marked by victory and defeat.

\section{DISCUSSION}

It can be acknowledged that far from conceiving decision making about brands as an entirely technology-mediated process, customer decision making and ultimately their purchase decisions are also agency-driven processes. There are multiple plausible options when it comes to social media influences. Social networks formed via social media may shape the choices students make when purchasing brands, or students' purchases may even be negatively affected by social media if those who purchased these brands based on social media advertising were conceived to end up making bad life choices (e.g. excessive drinking, addiction and socially immoral behaviours such as drug abuse). Alternatively, students may still choose to purchase or not to purchase independent of their social media advertising experiences. As Archer (2001) observes, agency is about how an individual's emergent powers are exercised on and in the natural, practical and social world in our triune environment, as much as it is about internal dialogues [about choices, which are not] only windows upon the world but rather are what determines our being in the world. In our view, students are not mindless pawns at the messy and vicissitudes of a technology-driven advertising world, rather they are calculative decision making agents that exercise agency in their choice of brands depending on their given academic, socialeconomic and cultural circumstances. As Archer (2001) observes, with the exercise of individual agency comes three inevitable concerns about: physical wellbeing, performative competence and individual self-worth. In view of the choices students make between Play and Monster Energy, therefore, it can be inferred that students make prudent brand choices that safeguard their emotional and intellectual wellbeing, and allow for the expression of their performative identities through consumption of brands. This is because the consumption of global energy drinks is positively associated with developing a contemporary global identity image among youths (Archer, 2001).

We also noted with the evolving nature of the Sematic Web how student decisions are being influenced by the technological affordances of social media, in particular the emotional appeal and attractiveness of such websites, social commentary and viral spread of messages. Since the debate about engaging recruitment agents is not only fraught with concerns about direct expenses in terms of commissions but also the reputational risk to institutions' brand (Redden, 2011), companies are increasingly turning to brand ambassadors and advertising on social media platforms to market their brands. Inconsistent with the popular claims about social media being a perfect storm that has rocked the youthtargeted advertising landscape, our study, revealed how social media platforms are ambivalent communicative 
platforms whose robustness in communicating brand traits depends on the logical intentions of brand managers, advertisers and the brand preferences of consumers.

\section{LIMITATIONS OF THE STUDY}

The study limitation lies in that it was largely theoretical in orientation-informed by our exploration of extant literature and our personal reflections on student engagement in social media-supported decision making about brands. While such a study can be critiqued for being founded largely on secondary data, its strength lays in its inter-subjective nature - capacity to drawn on existing scientific research allowing the researchers to be in conversation with these experts' findings, and authors' reflexivity based on students' experiences and their own experiences with social media.

\section{CONCLUSION AND MANAGERIAL IMPLICATIONS}

In the current study, which explored the impact of social media advertising on student brand preferences, we presented social media as the electronic market place where marketers and brand managers are ideally supposed to meet, engage and influence consumers' (especially students) decision making about brands (high energy drinks). This is critical as the new role of marketers is to understand that marketing is consumer driven and consumers are effective elements in marketing strategy (Loudon, Stevens, \& Wrenn, 2005). The challenge, however, is that in these ephemeral, nontargeted and message-lean advertisements, marketers are failing to sufficiently seize hold of consumers' decisions as these interactions are by proxy and indirect (i.e. via websites). Therefore, as consumers are changing the way they buy products, marketers are increasingly required to pay special attention to the consumer's purchase decision journey (Court, Elzinga, Mulder, \& Vetvik, 2009). In view of the complex choices that students make between Monster Energy and Play drink brands, marketing managers may need to counter the negative publicity that surround the former drink as well as augment the market of the latter through targeted research (Loudon et al., 2005). As literature suggests, marketing managers and marketers are under pressure to engage in ongoing market research, understand the market segments and determine and deliver products which satisfy the needs and wants of the target markets (Loudon et al., 2005). Once they have a clear understanding of the market requirements, marketing managers will be able to influence the consumers' purchase decision journey by developing and implementing marketing strategies which are customer focused and based on relationship building, knowledge management and information sharing (Ferrell \& Hartline, 2008). However, marketing managers and advertising managers may need to advise marketers and advertisers that a one size-fits-all intergenerational marketing approach does not work due to the uniqueness of individual consumers, their increasing heterogeneity and the agency they exercise over products when making consumption decisions in resource constrained academic environments.

Although research has indicated that traditional media (i.e. newspaper advertisements, promotions and word-ofmouth) is waning in comparison with digital media methods, research has also shown no decrease in consumer influences on brand purchases (Influencer50, 2008). Future experimental research, marketing managers, advertising managers and researchers may need to compare traditional and digital communication media consumed by students to empirically determine their authentic impact on student buying intentions, actual purchase decisions and their comparative satisfaction levels.

While traditional marketing has focused on consumer attitudes, information and mass marketing tactics, digital marketing (e.g. social media marketing) uses information obtained from data mining of actual consumer purchases to provide insights into consumer behaviour (Mulhern, 2009). Therefore, digital marketing provides some significant insight almost instantaneously compared to other marketing channels (Malhotra, 2010). However, in view of the agency that the youth exercises in choosing brands, the future empirical research of advertising and marketing managers and researchers should compare the purchase decisions that students make independent of social media advertising influences with purchase decisions that they make based on the same to determine which of these enable prudent consumption decisions.

Future studies can also compare student decision making about brands based on different kinds of social media (e.g. Facebook, Twitter, WhatsApp and YouTube). By comparing text-based to video-oriented social media or by comparing different instance of social media with different functionalities, researchers can then determine, consistent with Media Richness Theory, which characteristics in a particular communication medium give rise to richer, more accurate, and more adaptable content. 


\section{AUTHOR BIOGRAPHIES}

Dr Patient Rambe holds a PhD in Educational Technology from the University of Cape Town, South Africa. He holds the position of Senior Researcher in the Department of Business Support Studies at the Central University of Technology in South Africa. Dr Rambe is a Convener of the Masters and Doctoral Programme Stream at the same university. He previously served as a Postdoctoral Research Fellow and Assistant Director in the Office of International Academic Projects at the University of the Free State, South Africa. His recent co-authored book is entitled: Leveraging Educational Quality in Southern African educational systems: A practitioners' perspective.

Miss Reitumetse Joyce Jafeta is a Masters of Business Administration candidate at the Central University of Technology in South Africa. She graduated with a National Diploma and B-Tech in Office Management and Technology. She is currently working in the Faculty of Management Sciences as a Part-time lecturer, at Central University of Technology, Free State. Her current research focuses on the influence of social media advertising on consumer brand preference, a case of Monster Energy drink among select first year students at Central University of Technology, Free State.

\section{REFERENCES}

Aaker, D.A. (1991). Managing Brand Equity: Capitalizing on the value of a brand name. New York: Free Press.

Aaker, D.A. (1996). Measuring Brand Equity across productions and markets. California Management Review, 38(3), 102$20,174$.

Aaker, D.A. \& Joachimsthaler, E. (2000). Brand Leadership. New York: Simon And Schuster Inc.

Aguaded, J.I., Ferrés, J., Cruz Díaz, R. \& Delgado-Ponce, Á. (2011). Informe de investigación: el grado de competencia mediática en la ciudadanía andaluza. Huelva: Grupo Comunicar Ediciones/Grupo de Investigación Ágora de la Universidad de Huelva.

Alford, C. Cox, H. \& Wescott, R. (2001). The effects of red bull energy drink on human performance and mood, Amino acids, 21(2), 139-150.

Alhaddad, A. A. (2015). The Effect of Advertising Awareness on Brand Equity in Social Media. International Journal of eEducation, e-Business, e-Management and e-Learning, 5(2), 73-84.

Aljukhadar M., Senecal S. \& Ouellette D. (2010). Can the media richness of a privacy disclosure enhance outcome? A multifaceted view of trust in rich media environments. International Journal of Electronic Commerce, 14(4), 103126.

Archer, M. (2000): Being Human. The Problem of Agency. Cambridge, UK: Cambridge University Press.

Archer, M. (2001). Being Human: The Problem of Agency. Cambridge: Cambridge University Press.

Arora, T. (2013). Evolution of Ocular surface reconstruction. DOS Times.

Ba, S. \& Pavlou, P.A. (2002). Evidence of the Effect of Trust Building Technology in Electronic Markets: Price Premiums and Buyer Behavior, MIS Quarterly, 26(3), 243-268.

Barker, M., Barker, D., Bormann, N. and Neher, K. (2013). Social media marketing: A strategic approach, Cengage Learning: South Western, USA.

Bashar, A. Ahmad, I. \& Wasiq, M. (2012). Effectiveness of social media as a marketing tool: An empirical study. International Journal of Marketing, Financial Services \& Management Research, 1(11), 88-99.

Batra, R; Ahuvia, A \& Bagozzi, R. P. (2012). Brand Love. Journal of Marketing, 76(2), 1-16.

Bergin, R. (n.d.). Media Richness Theory Retrieved from: https://www.chds.us/coursefiles/IS4010/lectures/tech_media_richness_long/media/Media\%20Richness\%20Theor y\%20Script.pdf

Bernard, J., Hudson, K., \& Hunter, L., Liu, F. \& Murphy, J. (2008). The Google online marketing challenge: classroom learning with real money, and real advertising campaign, Journal of International Advertising, 9(1). Retrieved from: http://www.jiad.org/article109

Berthon, P. Pitt, L. \& Campbell, C, (2008). Ad Lib: When customers create the ad. California Management Review, 50(4), 6-30.

Bhargava, V. (2010). Twitter power. Retrieved from: www.slideshare.com.

Blackshaw, P., \& Nazzaro, M. (2006). Consumer-generated media (CGM) 101: word-of-mouth in the age of the webfortified consumer. New York: Nielsen BuzzMetrics.

Blackwell R.D, Miniard P.W \& Engel J.F, (2001). Consumer behaviour. 9th ed. Manson, OH: South-Western.

Bogomolova, S. \& Millburn, S. (2012). Reasons for non-consideration of brands and the role of prior experience. Journal of Brand Management, 19(4), 304-317.

Chattopadhyay, T. Shraddha, S. \& Krishnan, M, (2010). Marketing mix elements influencing brand equity and brand choice. Vikalpa: The Journal for Decision Makers, 35(3), 67-84. 
Chen, Q. Chen, H. M. \& Kazman, R. (2007). Investigating antecedents of technology acceptance of initial eCRM users beyond generation X and the role of self-construal, Electronic Commerce Research, 7(3-4), 315-339.

Chesnut, L. (2010). Raising a Monster Army: Energy Drinks, Masculinity, and Militarized Consumption. Master's Thesis, Graduate College, Bowling Green State University.

Copyright Company. (2008). Available: www.deiworldwide.com.

Court, D., Elzinga, D., Mulder, S., \& Vetvik, O. J. (2009). The consumer decision journey. McKinsey Quarterly, 3, 1-11.

Cruse, P. (2007). Van Fraassen on the nature of empiricism. Metaphilosophy, 38(4), 489-508.

Daft, R. L. \& Lengel, R. H. (1984). Information richness: A new approach to managerial behavior and organization design. In B. Staw, \& L. L. Cummings (Eds.), Research in Organizational Behavior, Greenwich, CT: JAI Press, $191-233$.

Dei Worldwide, (2008). Engaging Consumers Online: The Impact of Social Media on Purchasing Behavior. Retrieved from: http://themarketingguy.files.wordpress.com/2008/12/dei-study-engaging-consumers-onlinesummary.Pdf

Deliens, T. Clarys, P. De Bourdeaudhuij, I. \& Deforche, B. (2014). Determinants of eating behaviour in university students: A qualitative study using focus group discussions. BMC Public Health, 14, 53-53.

Dickinson, T. (2012). An Inefficient Choice: An Empirical Test of Media Richness and Electronic Propinquity. Masters Thesis, Graduate School, Ohio State University.

Ferrell, O.C. \& Hartline, M.D. (2008). Marketing management Strategy. $4^{\text {th }}$ Ed. Cengage Learning: South-Western.

Food Product Design, (2013). Natural colours driving global colours sector, Food Product Design Retrieved from: www.foodproductdesign.com/news/2013/02/natural-colours-driving-global-colors-secto.aspx

Fornicola, F. (2007). Energy Drinks: What's All the Buzz About? Coach \& Athletic Director 76(10), 38-43.

Freshman Consulting, (2010). Retrieved from: http://www.freshmannconsulting.com

Georgia State University Library. (2015). What are Empirical, Review and Theoretical sources? Retrieved from: http://research.library.gsu.edu/c.php?g=115857\&p=753960

Gu, R. Oh, L. B. Wang, K. (2016). Developing User Loyalty For Social Networking Sites: A Relational Perspective. Journal of Electronic Commerce Research, 7(1), 1-21.

Hay, D. (2009). A survival guide to social media and Web 2.0 optimisation: Strategies, tactics and tools for succeeding in social web. New Jersey: Dalton Publishing.

Heinonen, K. (2011). Consumer activity in social media: Managerial approaches to consumers' social media behavior. Journal of Consumer Behaviour, 10, 356-364.

Heinrichs J.H., Lim, J.S. \& Lim, K.S. (2011). Influence of social networking site and user access method on social media evaluation. Journal of Consumer Behaviour. 10, 347-355.

Himmel, B. (2008). Different Strokes for Different Generations, Rental Product News, 30(7), 42-46.

Hossain, M.M., Azad, N., Parveen, R. \& Masum, M. (2014). Effect of advertisement on purchasing energy drinks in Dhaka city of Bangladesh. European Journal of Business and Management, 6(7), http://www.researchgate.net/publication/268601013

Hsiao, M. H. (2009). Shopping mode choice: Physical store shopping versus e shopping. Transportation Research Part E: Logistics and Transportation Review, 45, 86-95.

Illumine Marketing \& Media, (2010). [Online]: www.slideshare.com.

Influencer50. (2008). The influence of WOM. White Paper, February 2008. URL: http://www.influencer50.com/.

Institut National De Santé Publique Du Québec, (2013). Energy drinks: Threatening or commonplace? An update. TOPO.

Ivanauskas G, (2009). The evaluation of social media effects on consumer marketing communications: The UK consumer's perspectives. Masters Thesis, London Metropolitan University.

Kaplan A.M \& Haenlein, M. (2010). Users of the world unite! The challenges and opportunities of social media. Business Horisons, 53, 59-68.

Kaplan, A. \& Haenlein, M. (2009). The fairyland of Second Life: Virtual social worlds and how to use them. Business Horizons, 52(6), 563-572.

Karam, A.A. Saydam, S. (2015). An Analysis Study of Improving Brand Awareness and Its Impact on Consumer Behavior Via Media in North Cyprus:A Case Study of Fast Food Restaurants. International Journal of Business and Social Science, 6(1), 66-80.

Kashani, N. (2010). Analysis Of Function Drink Brand Recognition. Bachelor of Science Degree, Faculty of the Agribusiness Department California Polytechnic State University.

Keller, M. (2012). Advertising and Consumerism in the Food Industry. Honors Theses -Providence Campus. Retrieved from: http://scholarsarchive.jwu.edu/student_scholarship/3

Kjeldgaard, D. \& Askegaard, S. (2006). The Glocalization of Youth Culture. The Global Youth Segment as Structures of Common Difference. Journal of Consumer Research, 33(2), 231-247.

Lan, Y. F. \& Sie, Y. S. (2010). Using RSS to support mobile learning based on media richness theory. Computers \& Education, 55(2), 723-732.

LaPointe, K., \& Heilmann, P. (2014). Daring leaps Construction of meaning and individual agency in career change narratives in the media. Nordic Journal of Working Life Studies, 4(2), 47-64.

Liu, C. \& Arnett, K. (2000). Exploring the Factors Associated with Web Site Success in the Context of Electronic Commerce. Information \& Management, 38(1), 23-33. 
Loudon, D. Stevens, R. \& Wrenn, B. (2005). Marketing Management. Binghampton: The Haworth Press Inc.

Malhotra, N. K. (2010). Marketing research: An applied orientation. $6^{\text {th }}$ Ed. Upper Saddle River, NJ: Prentice Hall.

Mandal, D. \& McQueen, R. (2012). Extending media richness theory to explain social media adoption by microbusinesses. FASSGRAD $2012-12^{\text {th }}$ Nov, 2012. Retrieved from:

https://www.academia.edu/4130175/Extending_Media_Richness_Theory_to_explain_Social_Media_Adoption_M icrobusinesses

Markus. M.L (1994). Electronic mail as the medium of managerial choice Organization Science. 5(4), $502-527$.

McDonald, M. \& Bradley, A. (2012). Managers need to up their game with social media. Harvard Business Review. Retrieved from: http://blogs.hbr.org/2012/03managers-need-to-up-their-game/

Moore, M. (2009). Does brand image or taste have more influence on consumer preference for energy drinks? The Honors Program, Senior Capstone Project. Retrieved from: http://digitalcommons.bryant.edu/cgi/viewcontent.cgi?article=1004\&context=honors_marketing

Morris, W. (1982). The American Heritage Dictionary, 549.

Mulhern, F. (2009). Integrated marketing communications: From media channels to digital connectivity. Journal of Marketing Communications, 15(2-3), 85-101.

Muntinga, D. G. Moorman, M. \&. Smit, E. D. (2011). Introducing COBR as Exploring Motivations for Brand-Related Social Media Use. International Journal of Advertising, 30(1), 13-46.

Ni, J., Jiang, B. \& Srinivasan, K. (2014). Signaling through pricing by service providers with social preferences. Marketing Science, 33(5), 641-654.

Okazaki, S. (2009). Social influence model and electronic word of mouth. International Journal of Advertising, 28(3), 439472.

Online Testing eXchange (OTX) Research, (2008). Impact social media on purchasing behavior. for DEI Worldwide in August 2008. Retrieved from: http://www.deiworldwide.com/files/DEIStudy-Engaging\%20ConsumersOnlineSummary.pdf

Rambe, P. (2009). The Impact of Social Networking Sites on Academic Relations and Student Learning in University Settings. PhD. School of Education, UCT.

Rambe, P. (2012). Social media-enhanced phones for productive learning of South African postgraduate students. International Journal of Mobile and Blended Learning, 4(2), 49-66.

Red Bull Energy Drink, (2008). FAQ. Retrieved from: http://www.redbull.com/\#page=ProductPage.FAQS.

Redden, E. (2011). SUNY bets big on agents. Inside Higher Education. Retrieved from: http://bit.ly/sNAJBz

Reid, J.L. Hammond, D. McCrory, C. Dubin, J.A. \& Leatherdale, S.T. (2015). Use of caffeinated energy drinks among secondary school students in Ontario: Prevalence and correlates of using energy drinks and mixing with alcohol. Canadian Journal of Public Health, 106(3), 101-108.

Riegner, C. (2007). Word of mouth on the web: The impact of web 2.0 on consumer purchase decisions. Journal of Advertising Research, 47(4), 436-447.

Rietjens, B. (2006). Trust and Reputation on Ebay: Towards a Legal Framework for Feedback Intermediaries. Information \& Communications Technology Law, 15(1), 55-78.

Schultz, D, E \& Block, M. P. (2011). What External factors influence recommenders to recommend? Presented at ICORIA, Berlin Germany.

Seifert, S. M., Schaechter, J. L., Hershorin, E.R., \& Lipshultz, S. E. (2011). Health effects of energy drinks on children, adolescents, and young adults. Pediatrics, 127(3), 511-528.

Shepherd, M. M. \& Martz, W. B. (2006). Media richness theory and the distance education environment. Journal of Computer Information Systems, 47(1), 114-122.

Sheth, N.J. \& Mittal, B. (2004). Consumer behaviour: a managerial perspective. $2^{\text {nd }}$ Edition, South Western Publishing Company: New Jersey.

Shiue, Y. C., Chiu, C. M., \& Chang, C. C. (2010). Exploring and mitigating social loafing in online communities. Computers in Human Behavior, 26(4), 768-777.

Silverman, G. (2001). The Secrets of Word-of-Mouth Marketing. USA: Kogan Page.

Simon, S.J. \& Peppas, S.C. (2004), An examination of media richness theory in product Web site design: An empirical study. Info 6(4), 270-281.

Solomon, M. Bamossy, G. Askegaard, S. \& Hogg, M. (2010). Consumer Behavior: Buying: A European Perspective. $4^{\text {th }}$ Ed. Financial Times Press.

Spiegler, E. Michahelles, F. \& Hildebrand, C. (2011). Social Networks in Pervasive Advertising and Shopping. In: Müller, J, Alt, F., and Michelis, D. (eds.) Pervasive Advertising: Human computer interaction series, London: Springer Verlag, 207-225.

Statistica, (2016). Leading social networks worldwide as of January 2016, ranked by number of active users (in millions). The Statistics Portal. Retrieved from: http://www.statista.com/statistics/272014/global-social-networks-rankedby-number-of-users/.

Subhani, M.I. \& Osman, A.I. (2009). A study on the association between brand awareness and consumer/brand loyalty for the packaged milk industry in Pakistan. Munich Personal RePEc Archive No. 21367, Iqra University Research 
Centre (IURC), Iqra University, Karachi, Pakistan. Retrieved from: https://mpra.ub.unimuenchen.de/21367/1/MPRA_paper_21367.pdf

Sukoco, B.M. \& Wu, W.Y. (2010). The personal and social motivation of customers' participation in brand community. African Journal of Business Management, 4(5), 614-622.

Susic, A. (2014). Plain packaging on energy drinks: A quantitative study examining the effects of generic packaging of energy drinks on consumer attitudes and perceptions. Bachelor's Thesis. Department of Marketing and Strategy, Stockholm School of Economics, Stockholm, May 2014.

TechCrunch, (2012). Facebook Launches Verified Accounts and Pseudonyms. Retrieved from: http://techcrunch.com/2012/02/15/facebook-verified-accounts-alternate-names/

Temkin, B. (2010). The Customer Experience Index: for Customer Experience Professionals. Retrieved from: https://www.adobe.com/enterprise/pdfs/customer_experience_index_2010.pdf

Thackery, R. \& Neiger, L. (2009). A multidirectional communication model: implications for social marketing practices. Health promotional practise 10(2):171-175.

Thompson, C. J. \& Arsel, Z. (2004). The Starbucks Brandscape and Consumers' (Anticorporate) Experiences of Glocalization. Journal of Consumer Research, 31(3), 631-642.

University of Sydney (2016). Theoretical article (essay) structure: Rules \& common mistakes Retrieved from: http://www.psych.usyd.edu.au/current_students/writing_guides/essayA.shtml.

Vallacher, R. R. \& Wegner, D. M. (1989). Levels of personal agency: Individual variation in action identification. Journal of Personality and Social Psychology, 57, 660-671.

Van Den Eynde, F., Van Baelen, P. C., Portzky, M. \& Audenaert, K. (2008). The effects of energy drinks on cognitive performance, Tijdschrift voor psychiatrie, 50(5), 273-281.

Wacker, J.G. (1998). A definition of theory: research guidelines for different theory-building research methods in operations management. Journal of Operations Management, 16, 361-385.

WARC News, (2010). Coca-Cola, PepsiCo turn to social media. Word of Mouth Marketing Association (WOMMA). Retrieved from:http://www.warc.com/Content/News/N26443_CocaCola2c_PepsiCo_turn_to_social_media.content

World Bank, (2012). Chapter 4: Promoting women's agency. World Development Report 2012: Gēnder Equality and Development. (pp. 150-192). The World Bank: Washington, DC. https://issuu.com/world.bank.publications/docs/9780821388105

Yadav, N. (2012). Social Networking Sites-A New Vehicle for Advertising. MIMT Journal of IT \& Management Research, $2(1), 38-48$. 